\title{
Development of a Compact Captive Balloon and Its Level Supporting
}

\author{
中 尾 達 也*2 藤 原 和 人 $^{* 3} \cdot$ 古 川 索 康*2 廣 江 哲 幸*3 \\ Tatsuya Nakao, Kazuhito Fujiwara, Motoyasu Furukawa and Tetsuyuki Hiroe
}

Key Words : Captive Balloon, Kite, Stabilization

\begin{abstract}
Many kinds of observation techniques have been developed to obtain the properties of atmospheric conditions. The advanced observation techniques of the flow in relatively large scale are remote sensing by satellite facilities, long range observations by radar or Doppler Sodar, etc., while data from conventional climometers set at fixed places are merely limited information about local scale flow. Captive balloons are also available and feasible for the observation of local flows if their standing mechanics are robust against the strong wind and the motion of balloon are stable for all wind direction and the change of wind direction. In this paper, a compact captive balloon (about $2 \mathrm{~m}$ diam.) for flow measurement is proposed and the preservation of balloon height level and the stabilization of its motion are challenged by using a kite. The relation between force balances acted on the balloon and the balloon height or position was estimated and confirmed in experiments. Although the lift force of single kite worked successfully, it is found that the performance of plural kites is less in the traction of balloon since the interaction of their tensions. The compact balloon supported by the kite enabled the over $300 \mathrm{~m}$ floating by virtue of the small size causing only low air resistance.
\end{abstract}

\section{1. は じめに}

気象を観測する際には, 対象としている現象の空間的 , 時 間的スケールに応じて観測システムを決定しなければなら ない.近年, ヒートアイランド現象や局地風など地表付近 から高度 $1000 \mathrm{~m}$ 程度までの領域 (大気境界層) で起こる， 局地的な気象のメカニズムを明らかにしようとする試みが なされている. 兴のような現象は水平スケールか数十 $\mathrm{km}$ 以下, 時間スケールが数時間以下という小さいスケールで 起こるために，気象要素の中でも局地性の大きな要素を知 ることが重要となり，乥の観測には高い空間分解能と時間 分解能が求められる.

以上のことよりまとめると，局地気象を観測するための 機器に求められる要件は「大気境界層内において, 局地性 の大きな気象要素を高い空間・時間分解能で観測可能であ ること」と言えよう．

局地性の大きな気象要素としては, 風(風向・風速) が 挙げられるが, 現在, 風の観測に用いられている機器の中 で, 前述の要件を考慮すると, 係留気球は有効な観測機器 であると言える . 係留気球は異なった種類のデータを一度 に直接的に計測できるという利点も有しており，これまで にも大気鉛直構造の観測の他, エアロゾルや温室効果ガス などの観測にも用いられてきた .

\footnotetext{
*1 C) 2005 日本航空宇宙学会

平成 13 年 11 月 9 日, 日本航空宇宙学会西部支部講演会 (2001) において一部発表. 平成 15 年 10 月 8 日原稿受理

$* 2$ 熊本大学大学院自然科学研究科

$* 3$ 熊本大学工学部
}

係留気球以外で大気境界層内の風の観測に用いられてい る機器を挙げると, 直接的な計測を行うものとしては, よ く知られている気象観測システムAMeDAS (Automated Meteorological Data Acquisition System) で用いられて いるような風向風速計があり，間接的に計測を行うものと しては, ドップラーソーダやウィンドプロファイラなどが

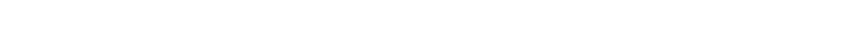
気象を対象とした場合，空間分解能が十分でない，計測の 範囲か限定される, 気象条件の变化により計測誤差が大き くなる，といった短所がある．

高層気象の領域ではレーウィンゾンデによる風の観測も 行われているが, 第 1 図 ${ }^{1,2)}$ に示すように地表付近と高層 領域では風速の相関が小さく，高層のデータによる低層の 風の推定が困難であることから，地表付近の風を知るには 実際の観測が求められる . また , ゾンデでは一定領域の連 続的な観測ができないため, 局地的な風の観測には適して いない．このように他の観測手段と比較しても，係留気球 は局地気象の観測に便利な機器であると言える .

しかし，係留気球にも（1）強風時の係留 (定位置保持) が困難，(2) 気球と積載物の重量に対して十分な浮力を得 るために大型化，(3) 材料のガス封入性能の問題により浮 力の維持が困難，(4) 計測装置や通信装置への電力供給の 問題，といった短所があり，乥の使用は短時間の計測に制 限されているのか現状である.

本研究では局地気象観測用小型係留気球の開発を目指し， これらの短所を克服することを考える．弚の中でも強風時 の係留が困難であるという点が大きな妨げとなっており，係 留気球を活用するには浮遊安定性の改善か強く求められる. 


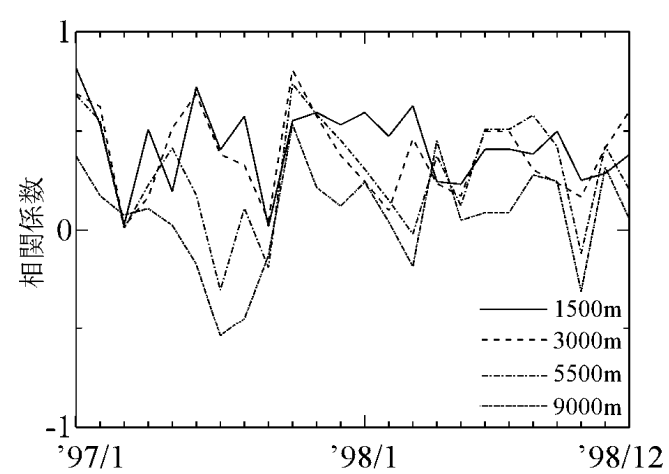

第1図 福岡での高層と地表付近の風速における相関係数（気象デー タひまわり CD-ROM99，2000 より算出)

しかし，前述のように係留気球には積載機材への電力供給 という問題があるため, 浮遊安定性を改善するために電気 的な装置を用いるのは好ましくない，本論文では小型係留 気球の開発と共に，凩を用いた光の浮遊安定性改善効果に ついて報告する．

\section{2. 小型係留気球について}

係留気球の形状は回転棈円体型，球冠型，円錐型から静 止浮遊時の直径，表面積，投影面積，直径と高さの比（縦 横比)，抗力 , 慣性モーメント，振動の周期について予備検 討を行い, 縦横比 0.45 の回転楕円体が最適であるという結 論を得た。

気球の小型化と係留の長時間化を图るために，弚の材料 には軽量でガス封入性能が高いアルミ蒸着エバール樹脂多 層フィルムを用い， 円形に切り取った 2 枚のフィルムの周 を熱で互いに接着することで製作した . 試作により気球の 縦横比が 0.6 程度になることが分かったが, 製作の容易さ を考慮し，この製作法を用いた。

高強度で軽量かつ細さが求められる係留系には, ケブラ 緎維（直径 $1.5 \mathrm{~mm}$, 単位長さ当たり質量 $1.28 \mathrm{~g} / \mathrm{m}$, 引張 強度 $700 \mathrm{~N})$ を選定し，気球に注入するガスにはヘリウム を用いた。

気球と係留系との取り付けは, 強度の観点から気球を包 み込む帯状のカプトン樹脂フィルムを介することで，係留 系の張力が直接気球に作用しないよう工夫を施している.

気球の寸法を決定するに当たり，第 2 図に示すような静 止浮遊状態における力の釣合を考えると, 気球の釣合方程 式は次のように表される .

$$
V\left(\rho_{\text {Air }}-\rho_{\text {He }}\right)-\left(\rho_{\mathrm{m}} t S+M+m l\right)=0
$$

ここで $V:$ 気球の体積, $\rho_{\mathrm{m}}$ : 気球材料の密度, $t:$ 気球材 料の厚み, $S$ : 気球の表面積, $M$ : 積載物の質量, $m$ : 係留系 の単位長さ当たり質量, $l:$ 係留系長さであり, 必要な気球 の体積 $V$ は $M$ と $l$ を与えることで求まる. $M$ を $1700 \mathrm{~g}$, $l$ を $200 \mathrm{~m}$ として, 気球の寸法形状を直径が $1.9 \mathrm{~m}$, 高さ が $1.1 \mathrm{~m}$ の回転棈円体と決定した .

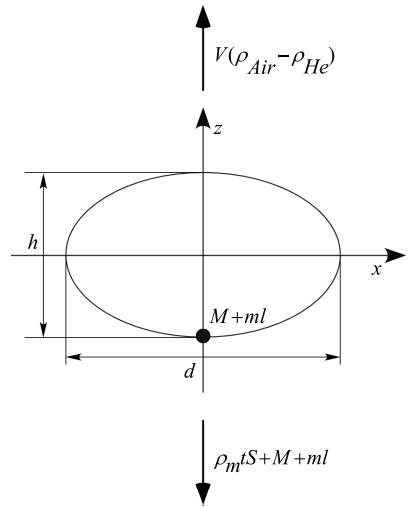

第 2 図 静止浮遊時の力の釣合

\section{3. 凩を用いた気球の浮遊安定性改善}

係留気球を用いて長時間の観測を行うためには，変化す る気象条件に対応し安定した係留を行うことが必要である が, 特に問題となるのは強風時における係留高度の低下で ある 。

ここで师を用いた気球の浮遊安定性改善 (係留高度保持) 法について述べる．

第 3 図に示すような気球の抗力係数を一定 (気球の傾き 無し) として簡略化した凩一気球モデル（以下，モデル A と呼ぶ）を考える.気球の余乘浮力を $B$ ，抗力を $D_{\mathrm{B}}$ ，㶡 の揚力を $L_{\mathrm{K}}$ とし，係留地点から师までの距離を $l_{1}$ ，师か ら気球までの距離を $l_{2}$ とすると， $l_{1} \gg l_{2}$ のとき，気球の 係留角度 $\theta$ (地上の係留点と気球を結い湶が水平面となす 角) は以下のように表される.

$$
\theta \approx \tan ^{-1}\left(\frac{B+L_{\mathrm{K}}}{D_{\mathrm{B}}}\right)
$$

师は無風状態において, 気球に対する重りとして働くが， 風を受けたときには揚力を発生するため，気球だけを係留 した場合に比べて高度が高く保たれる．このように，必要 とされるときに機械的に係留高度を高く保つ効果をもたら すことができる，という点がこの手法の特徵である .

気球に取り付ける㶡は, 市販されている凩 (翼長 1150 $\mathrm{mm}$, 全高 $600 \mathrm{~mm}$ ) から形状を決定しており，第 4 图に示 すのは光の特性を調べた結果である．寸法の決定に際して は, 風速 $20 \mathrm{~m} / \mathrm{s}$ の風を受けたときでも気球の係留角度を 60 度程度に保つことができるような揚力を発生する，とい う条件を与えた．凩の揚力係数として，第 4 図での迎角 30 度における平均値を仮に用いて揚力を見積もると，必要な 寸法は翼長が $2300 \mathrm{~mm}$, 全高は $1200 \mathrm{~mm}$ となった（第 5 図).この忛を気球に取り付けた樣子を第 6 図に示す .この 网の材料にはポリエチレンフィルムを用いている．

(2) 式には凩による抗力と重力が含まれていないが , 抗 カについては, 凩の飛揚試験を行った結果から，風速が大 きく佩が定常状態にあると見なせるときの抗力が気球の抗 力に対して 1 割程度と小さいことが分かり，重力について も，風速が非常に小さい場合を除いて，凩の揚力を含めた 気球の全浮上力の 1 割以下と小さかったため, 乥れ無 


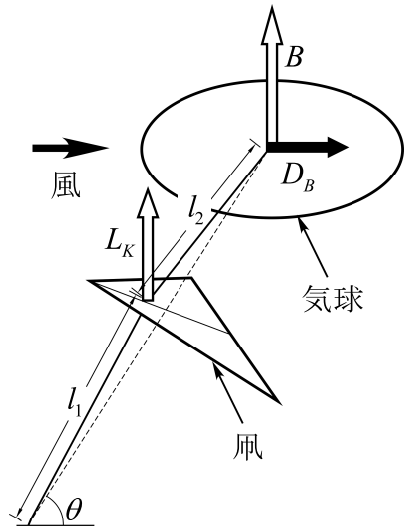

第 3 図 簡略化した用一気球モデル (モデル A)

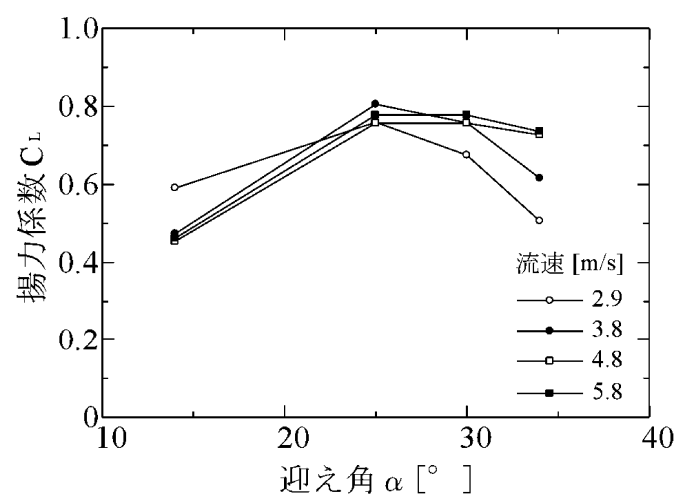

第 4 図 帅の性能曲線

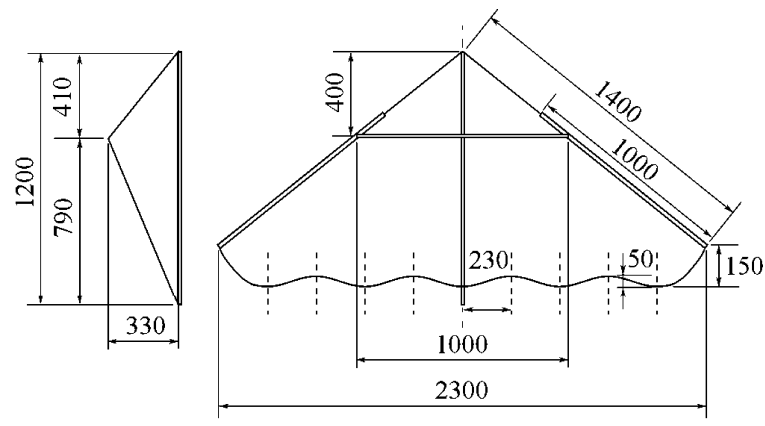

第 5 图凩の形状寸法

視したことによるものである .

\section{4. 浮遊安定性の改善効果}

师の効果を調べるために，係留した気球の動きをビデオ カメラで録画し，弚の軌跡を凩の有無によって比較すると いう手法をとった . 実験に用いた気球と凩については前述 の通りであり，㶡は第 7 図に示すような形で気球に取り付 けている．座標軸はビデオカメラを気球に向けた軸を $z$ 軸， $y z$ 平面が係留時の風の主流方向と平行になるように $y$ 軸 を定めた .

4.1 凩の有無による軌跡の比較 同気象条件 (同時刻) の下で，凩を取り付けた気球と凩を取り付けていない気球 を係留し，凩の効果を調べた結果について述べる .このと

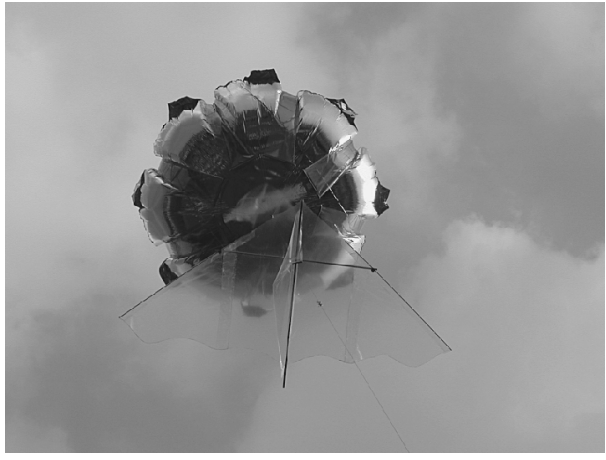

第 6 図気球に取り付けた凩
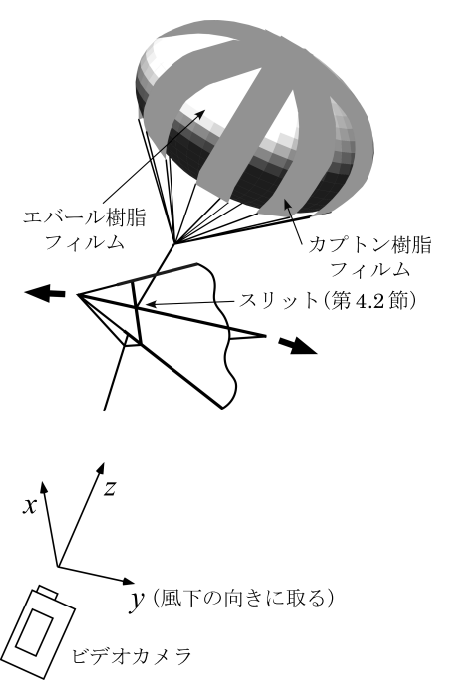

第 7 図凩の取り付け方法と座標軸

きの係留時間は 10 分，係留系長は $200 \mathrm{~m}$ で, 帆は気球の 中心から $3.2 \mathrm{~m}$ 下方に取り付けた .

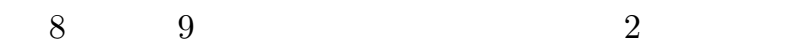
軌跡であり，これらの図では係留中の気球の平均位置を原 点に取っている.第 1 表には平均点からの距離の分散を示 す. 分散は $x$ 方向について 1 割程度大きくなったものの, $y$ 方向については㶡を付けていない場合の約 $1 / 4$ となった . ここで, 方向により值に差が出た理由を考察する.係留 系のたわみを無視すると, 気球は係留系の長さを半径とす る球面上を移動し, 軌跡図の $y$ 軸方向には主流方向の流れ による気球の移動か現れ， $x$ 軸方向には主流と直角な向き の流れによる気球の移動が現れる.$z$ 軸が鉛直上向きの場 合 (気球の平均位置が鉛直上方にある場合)，気球の高度 は原点からの距離によって決まり, 高度低下の割合は方向 によらないが，鉛直軸と $z$ 軸がある角度をなす場合，关の 角度が大きくなる (気球の平均高度が低くなる) につれて， 気球の高度変化は $x$ 軸よりも $y$ 軸の方向に現れる割合が 大きくなる .

第 8 図と第 9 图における $z$ 軸の方向も鉛直ではなく, 凩 を付けた場合に $y$ 軸方向の距離の分散が小さくなたのは， 凩によって気球の高度変化が抑制されたことの現れである と言える.一方, $x$ 軸方向に関して距離の分散が大きくなっ 


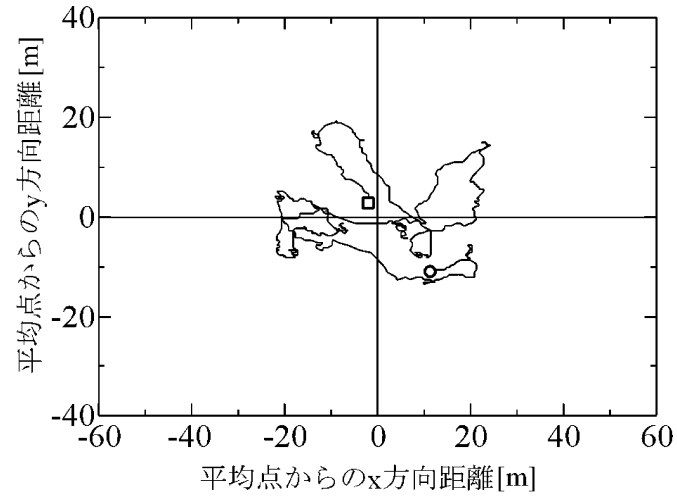

第 8 図気球の軌跡 (凩無し)

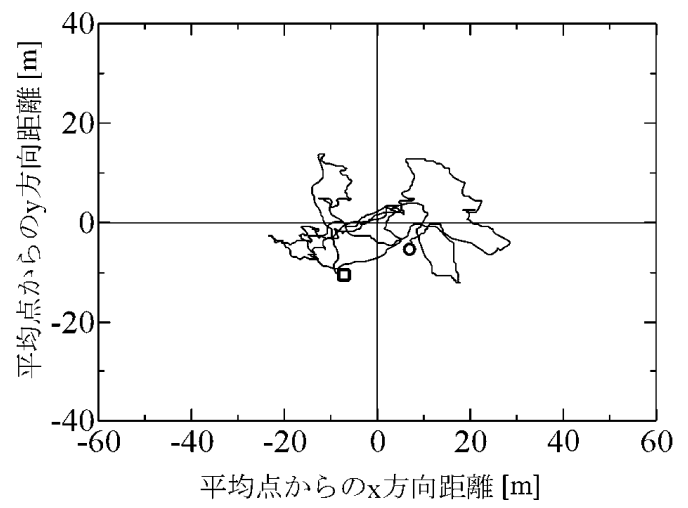

第 9 図気球の軌跡 (凩有り)

第 1 表 凩の有無による距離の分散の比較

\begin{tabular}{lrc}
\hline & 凩有り & 凩無し \\
\hline$x$ 方向距離の分散 $\left(\mathrm{m}^{2}\right)$ & 420.3 & 378.6 \\
$y$ 方向距離の分散 $\left(\mathrm{m}^{2}\right)$ & 66.5 & 270.4 \\
距離の分散 $\left(\mathrm{m}^{2}\right)$ & 119.2 & 118.0 \\
\hline
\end{tabular}

たのは気球と丽の相互作用によるものであろう . ビデオ画 像によると, 風向が変化したとき, まず気球が風下側に移 動し始め, 弚れに引かれる形で凩が移動するように見える。 兴のとき相対的な風向の変化に対して凩が過大応答するた めに主流と直角方向の変動か増加しているようである．

結果として距離の分散は凩を付けた方が大きい值となっ たが, 気球の定高度保持という観点から見ると, 凩の効果 が確認されたと言えよう.

4.2 凧の有無による係留角度の比較 第 7 図のように 凩を取り付けると，凩の迎角は係留系の傾きによって拘束 され，場合によっては凩の効率が下がってしまうことが考 えられた . 弚こで, 係留系が凩の骨を貫通している部分を スリット状に加工することで, 迎角に変化を持たせられる ようにした。このスリットにより迎角は 10.3 度 (増加方向 に 1.7 度, 減少方向に 8.6 度) の変化が可能である. これ は特に，気球の高度が低下したときでも迎角を小さく保ち， 师が失速状態になるのを防ごうとするものである .

この凩を用いて同気象条件の下て気球の係留を行い, 光

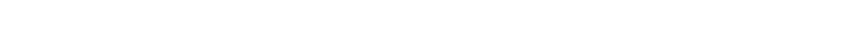

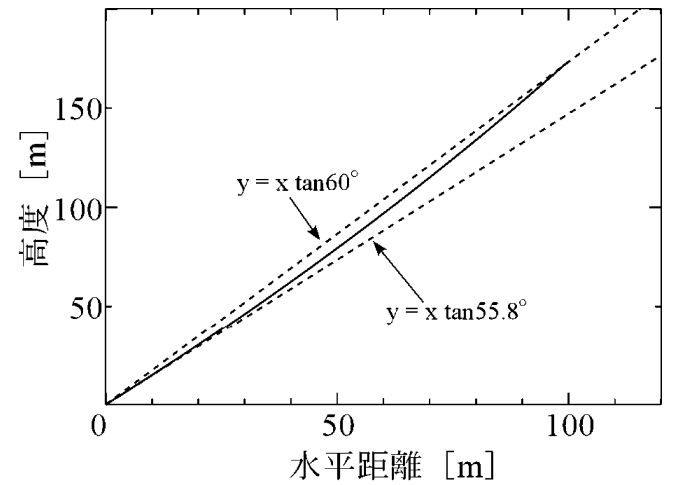

第 10 図 係留系の形状と係留角度との差異

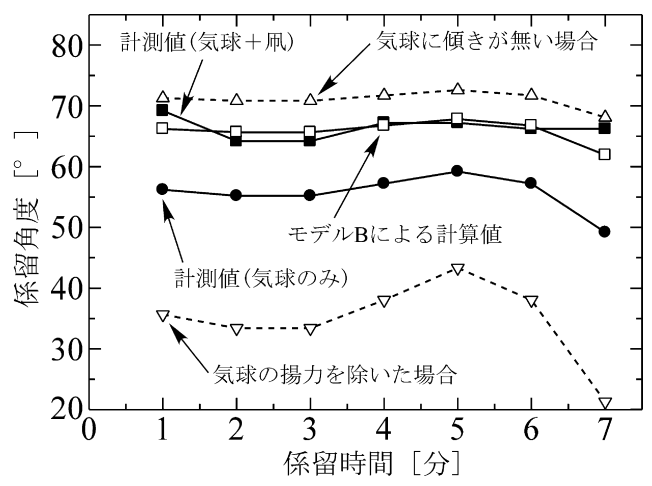

第11図 凩の有無による係留角度の比較

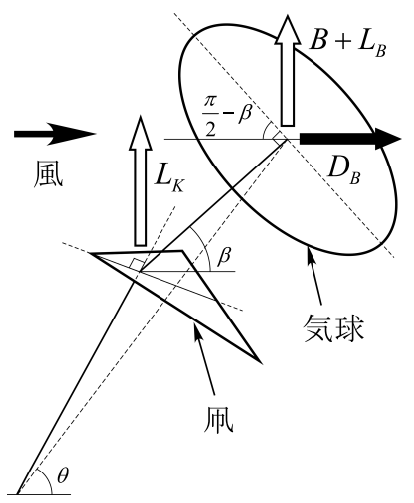

第 12 図気球の揚力を加味した凩一気球モデル (モデル B)

したこの角度は係留系に働く抗力と重力によってたわみが 生じるため, 実際の係留角度との間には差が生ずる．兰こ で係留系の形状を数值計算によって求め, 弚れらの角度の 差異を調べた .

係留系に働く力として, 張力, 重力, 抗力の 3 つを考え， 係留角度が $60^{\circ}$, 風速が $4.0 \mathrm{~m} / \mathrm{s}$ とした場合の系の形状を 第 10 図に示した . 系の張力は产のときの気球の浮力, 揚力 , 抗力から $26.5 \mathrm{~N}$ と与え, 系の抗力係数としては (長さ/直 径) の比が無限大の円柱に対する値 1.203) を用いた .これ によると，係留系の角度と気球の係留角度の間には約 $4^{\circ} の$ 差があることが分かる .

これを元に実験時の気球の係留角度を見積もり，プロッ トしたものが第 11 図である.この図には同時に, 第 12 図 
に示すような気球の抗力係数の変化と気球の揚力 $L_{\mathrm{B}}$ を加 味した凩一気球モデル (以下，モデル B と呼ぶ）を用いて， いくつかの場合について計算した係留角度もプロットして いる.これはモデル B において気球の係留角度と凩および 気球に働く力の関係から得られる .

$$
f(u, \theta, \beta)=\tan \theta-\frac{B+L_{\mathrm{K}}(u, \theta)+L_{\mathrm{B}}(u, \beta)}{D_{\mathrm{B}}(u, \beta)}=0
$$

を解くことによって求められる .

第 12 図で示したように，用と気球は乥れ光れ異なった 迎角を取ることができ，気球の迎角は風速によって決まる ため，(3) 式を解く際には，弚のときの風速から気球の迎 角 $(\pi / 2-\beta)$ を算出し, 前もって $L_{\mathrm{B}}$ と $D_{\mathrm{B}}$ を求めておく ことが必要である．実験時の風速については凩を取り付け ていない気球の係留角度から算出し, $4.1 \mathrm{~m} / \mathrm{s}$ から $6.1 \mathrm{~m} / \mathrm{s}$ という值を得た 。

第 11 図では実験から得た值は黑, 計算により得た值は 白で表している．実験から得た值は，黑の四角が师を付け た場合の気球の係留角度，黑丸が师を付けていない気球の 係留角度である . これらを比較すると师を付けた気球の方 が常に高い角度にあり，凩の効果か現れていると言える。

次に計算から得た值についてであるが, 白の四角で表さ れる点はモデル B を用いて計算した係留角度である．モデ ルBにおいても凩の抗力を考慮していないが, 关の点に対 応する実験值 (黑の四角点) と良く合致していることから 凩の抗力の影響は小さいことが分かる.気球の抗力と比較 して凩の抗力は小さいと考え，無視するとした仮定の妥当 性が確認されたと言えよう.

上向きの三角で表される点はモデル B で気球の傾きが無 いとした場合 (モデル A とは凩の揚力係数を定数としてい た点が異なる) であり，気球の抗力が小さい一方，気球に よる揚力は発生しない．この点と白い四角点の差は気球が 傾くことによる抗力増加と揚力発生の効果が合わさって生 じたものであると考えられる .

この抗力増加による影響が上三角点の值とモデル B から 気球の揚力のみを除去したとして計算された下三角点の値 の差として表れており，この点と白い四角点の值の差は気 球による揚力の効果であると見ることができる .

乥して，この白い四角点と黑丸点の差が师による揚力の 効果によるものであると言える．これによると，気球が発 生する揚力の効果は凩の揚力と比へても大きいことが分か る.しかし，凩の寸法を決定した際には気球の揚力発生や 抗力増加を考慮していないモデル A を用いていたため，モ デル B を用いて凩の翼面積の再検討を行った . 第 13 図に 示すのは (3) 式より求めた, 翼面積を变化させたときの風 速と係留角度の関係である。

図中の $n$ は翼面積が翼長 $2300 \mathrm{~mm}$ の凩の $n$ 倍であるこ と (凩の数) を示す. 図中に不連続な段差がいくつか見ら れるが, これは気球または凩の迎角か増加し, 失速状態に なって，得られる揚力が咸少したために生じたものである．

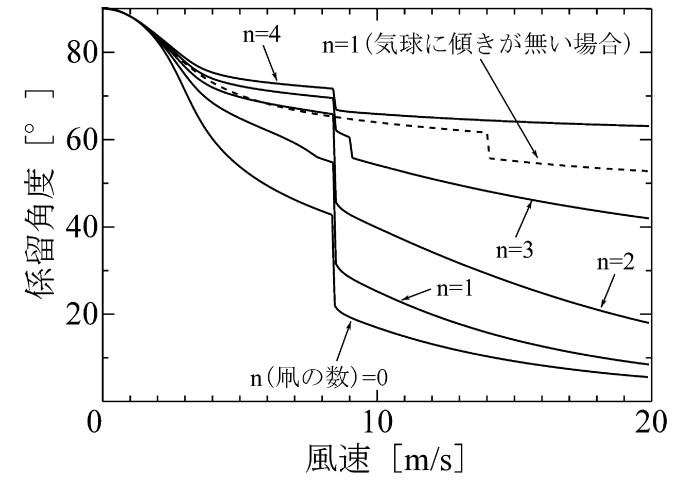

第 13 図 数値計算による㶡の数と気球の係留角度の関係

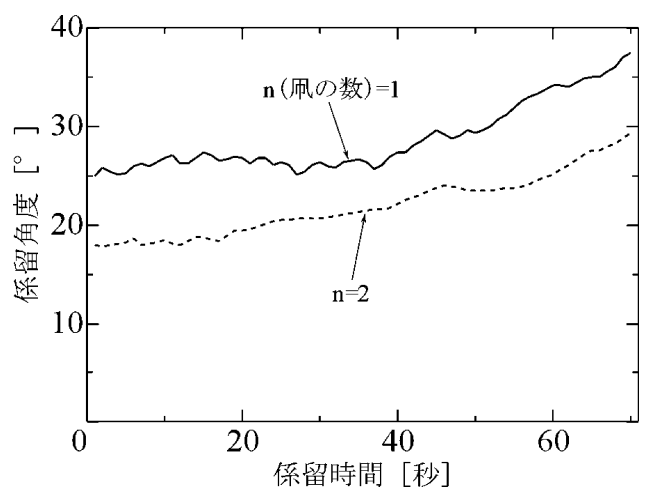

第 14 図 师の数による係留角度の比較

ここで, 凩の数にかかわらず風速 $8.5 \mathrm{~m} / \mathrm{s}$ 付近で段差が見 られるのは, 前述のように風速によって気球の迎角が決ま り，光の角度が失速角となる風速が約 $8.5 \mathrm{~m} / \mathrm{s}$ であるから である.また係留角度で見て $60^{\circ}$ 付近に見られる段差は师 の失速によるものである .

これより，風速 $20 \mathrm{~m} / \mathrm{s}$ という条件の下で気球の係留角度 を $60^{\circ}$ 以上に保つには, 4 倍の翼面積が必要になることが 分かった . また，破線で示したのはモデル B で気球が傾か ないとした場合（第 11 图での上三角点に相当）であるが， 気球の傾きを抑えることも係留角度を保つには効果がある ことが分かる。

4.3 师の増加による効果 师の翼面積を 4 倍にすると 弚の翼長は $4.6 \mathrm{~m}$ になり，製作や使用が困難になると考え られたため，凩の数を増やすことで対処することにした . 複 数の凩を用いても期待される効果が得られるか調べるため に，2つの凩を取り付けた気球の係留実験を行った．㶡は

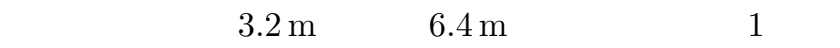
つ取り付けてあり，両方の凩の骨にスリット加工が施され ている.軌跡と係留角度を比較するため，凩を 1 つ付けた 気球の係留も同時に行い，係留系長を $200 \mathrm{~m}$ として 70 秒 間に渡って気球の軌跡を記録した。

第 14 図は光の軌跡から求めた 2 つの気球の係留角度を 示したもので, このときの風速は係留角度より $8 \mathrm{~m} / \mathrm{s}$ 程度 であつたと考えられる . 凩が 2 つの場合の係留角度は师が 1 つの場合よりも小さくなっており，凩を増やした効果が 現れているとは言えない，地上からの観察によっても，凩 


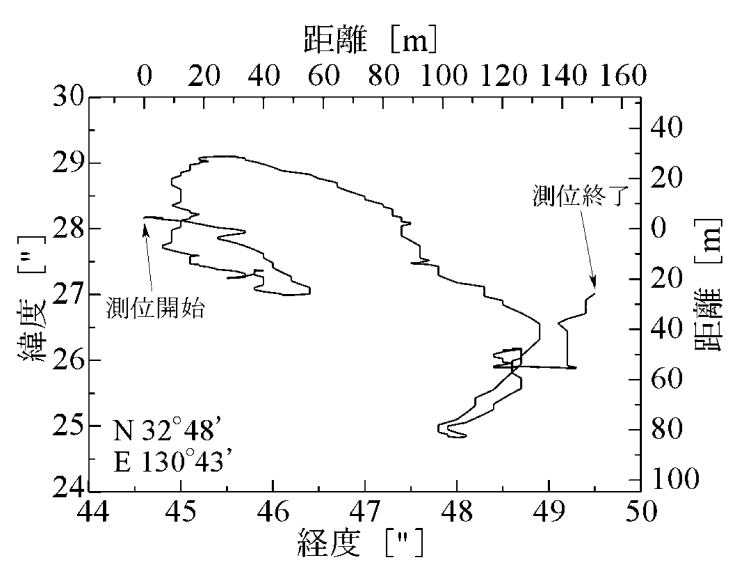

第 15 図 DGPS による気球の水平位置

が 1 つの場合の動きは比較的安定していたのに対し，片が 2 つの場合には回転や上昇・下降を繰り返す不安定な状態 か確認された .これは，このときの風速が第 13 图において 係留角度が不連続になる值付近であったことと，凩にかか

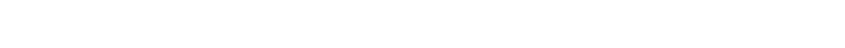
化したためであると考える．凩を複数用いて期待された効 果を得るには，凩の取り付け方法を工夫し，相互に影響を 与えないような構造にすることが必要である．

\section{5. 気球の位置の計測}

小型係留気球を用いた計測例として，凩を 1 つ付けた気 球にDGPS (Differential Global Positioning System) を 搭載して計測した気球の水平位置を第 15 図に, 気球の高 度を第 16 図に示す。

第 15 図において計測開始直後に気球が上昇していると きの軌跡から，高度によって風向が異なっていることが分 かる．これは係留地点が河川敷であったことから，河川や

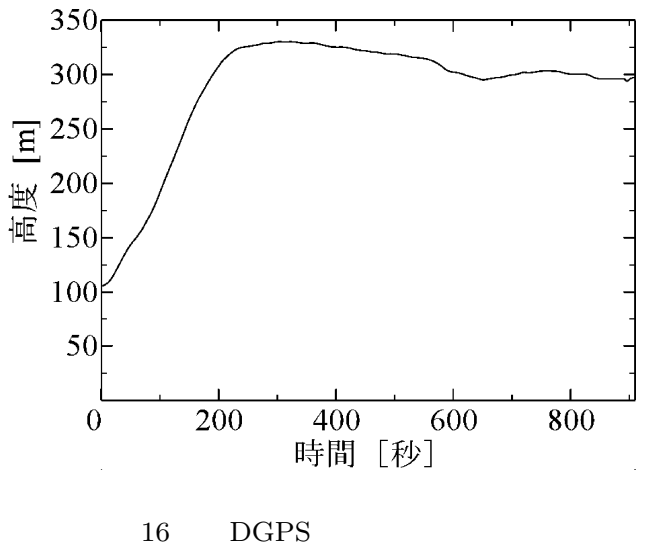

地形の影響を受けているためであると考えられる．また第 16 図では, 計測開始から約 600 秒後に高度か下がっている ことより，光のときに風が強くなったことが分かる．

$$
\text { 6. まと め }
$$

以上, 小型係留気球の浮遊安定性を改善するために㶡の 揚力を利用することを提案し，実験によって光の有効性を 確認した . 主流方向と直角な流れに起因する動きを抑制す るためには別の手法を考える必要があるが, 凩の面積を増 やし，気球の傾きを抑えるような機構と組み合わせること で，局地気象観測の実用に十分な浮遊安定性を得られるで あろうと考える。

$$
\text { 参 考 文 献 }
$$

1）日本気象協会: 気象データひまわり CD-ROM99, 丸善, 東京, 1998

2) 日本気象協会 : 気象データひまわり CD-ROM2000, 丸善, 東京, 1999.

3) 中山泰喜: 流体の力学, 養賢堂, 東京, 1998. 